University for Business and Technology in Kosovo

UBT Knowledge Center

UBT International Conference

2012 UBT International Conference

Nov 2nd, 9:00 AM - Nov 3rd, 5:00 PM

\title{
Tirana Urban Growth During The Last Decade
}

Arbi Shehu

ALUIZNI - General Directorate, arbishehu@gmail.com

Follow this and additional works at: https://knowledgecenter.ubt-uni.net/conference

Part of the Architecture Commons

\section{Recommended Citation}

Shehu, Arbi, "Tirana Urban Growth During The Last Decade" (2012). UBT International Conference. 28.

https://knowledgecenter.ubt-uni.net/conference/2012/all-events/28

This Event is brought to you for free and open access by the Publication and Journals at UBT Knowledge Center. It has been accepted for inclusion in UBT International Conference by an authorized administrator of UBT Knowledge Center. For more information, please contact knowledge.center@ubt-uni.net. 


\title{
"TIRANA URBAN GROWTH DURING THE LAST DECADE"
}

\author{
Ph.D. Cand. Arbi SHEHU ${ }^{1}$ \\ ${ }^{1}$ ALUIZNI - General Directorate, Tirana, Albania, \\ arbishehu@gmail.com
}

\begin{abstract}
After the 90s Tirana encountered a large increase of the population coming from different towns and villages of the country. In this way the population of 150 thousand inhabitants turned in approximately 1 million. Its major transformation has occurred in the last decade where beside the residents, a lot of settlements and socio-economic buildings have been constructed, bringing in this way an unplanned urban development.

To identify Tirana urban growth, in addition to terrain identification or partial urban studies more easily we canuse satellite images provided by Google Maps, which through their electronic archive provide us images over the years.

In this way, the paper at hand provides a visual analysis of the images over a decade, in 2002 and 2009. These images, which are within the yellow line in Tirana but also in its surroundings, show that part so called the Tirana Metropolis.
\end{abstract}

Key Words: Urban Growth, Satellite Imagery, Tirana, Albania. 